DOI: $10.31168 / 0459-6.43$

А. Н. Красовеи (Москва, Россия)

\title{
Вопросы транскультурности в романе Горана Войновича «Джорджич возвращается" (2021)
}

Роман словенского писателя, режиссера, сценариста и колумниста Горана Войновича (р. 1980) «Джорджич возвращается» («Đorđić se vrača», 2021) представляет собой продолжение его дебютного романа «Чефруры, вон!» («С̌efurji raus!», 2008), ставшего культовым в Словении и сделавшего из Войновича одну из ключевых фригур словенской литературной сцены. Писатель как никто другой до него раскрыл тему переселенцев из южных республик бывшей Югославии в Словении (которых словенцы пренебрежительно называют «чефурами»), обращаясь к логике стереотипа, юмору и уникальному языку иммигрантов первого и второго поколения, смеси словенского, сербохорватского и люблянского уличного сленга; этот сложный язык в итоге получил документальный статус. Благодаря данному тексту «идея чефрурства» также приобрела свои фантазийные рамки и уникальную, свойственную только ей, имажинерию, фрункционируя таким образом и на символическом уровне (Babnik 2021). Между выходом двух книг прошло тринадцать лет, тем временем увидели свет два других романа Войновича — «Югославия - моя страна» («Jugoslavija, moja dežela», 2012) и «Инжир» («Figa», 2016), которые, как и его дебютный роман, были удостоены награды «Кресник», присуждаемой газетой «Дело» за лучший словенский роман года. Продолжая тематику переселенцев и общего когда-то югославского пространства, раздвоенной, кочующей идентичности и наложения многослойных пространств, писатель поднимает в этих произведениях глубокие, фрилософрские проблемы войны, национализма, ненависти и прощения. Так и его последний роман несет на себе отпечаток этой авторской 
зрелости и новый, серьезный, временами мрачный тон. Желание вернуться к героям «Чедруры, вон!» и представить, что стало с ними десять лет спустя, Войнович объясняет своей озабоченностью актуальным состоянием вещей в Словении, на Балканах и шире во всем мире: «Роман "Джорджич возвращается” возник именно потому, что я хотел написать о том, как этот мой мир погружается обратно в темноту. Я хотел показать, что делает с людьми мрак, вновь спускающийся на Балканы, что делает с людьми безысходность и абсолютный крах общества, что делает с людьми национализм, стоит ему заполучить в свою власть государство <...>. Мы некоторым образом возвращаемся во времена нащиональной нетерпимости, популизма, безнадежности. В какой-то момент мне показалось, что, возможно, Марко Джорджич, его мир и мир его героев, язык, на котором он говорит, и есть тот способ, при помощи которого я смогу наилучшим образом выразить то, что чувствую» (Milek 2021) ${ }^{1}$.

Несмотря на более серьезную тональность, более глубокий и суровый взгляд главного героя на окружающую действительность, взгляд, на который наложило отпечаток десятилетнее пребывание в Боснии, превратившее энергичного подростка в молодого мужчину, полного обиды и агрессии, его внутренний монолог всё так же проницательно остроумен, ироничен и поражает своей языковой пластичностью, впечатляющей еще большей выразительностью по сравнению с «Чефруры, вон!». Именно стилистическая и формальная связь между романами позволяет им образовать единое целое, демонстрируя писательское мастерство Войновича. Структура романа всё та же - это главы, отвечающие на вопросы и, как правило, апеллирующие к стереотипам: «Почему для чефруров отец — это бог?», «Почему Фужины - это спальный район?», «Почему у чефруров нет офисов?», «Почему кредиты уничтожили чедуров?», «Почему Словения никогда

1 Здесь и далее перевод со словенского мой. $-A . K$. 
ничего не добьется в баскетболе?» и т.д.; юмористический элемент всегда выступает поводом для более углубленного социокультурного и психологического анализа.

Так, дебютный роман Войновича повествует о жизни люблянского спального района Фужины, где обитают переселенцы из бывших югославских республик; всё это показано глазами семнадцатилетнего Марко Джорджича, сына иммигрантов из Боснии, в жизни которого начинают возникать сложные повороты после того, как тренер исключает его из баскетбольной команды за неподобающее поведение. В новом романе мы встречаемся с Марко десять лет спустя, попрощавшись с ним когда-то у его родственников в Високо, куда его отправил отец Радован, чтобы спасти от преследований со стороны полиции. Здесь мы имеем дело уже с другим Марко, десять лет в Боснии лишают его привлекательной невинности. Он возвращается на Фужины, чтобы поддержать больного раком отца и, возможно, остаться здесь насовсем; его родной район, однако, изменился до неузнаваемости. Да и сам Марко теперь располагает более широкой картиной происходящего, ввиду чего и осознание им последнего гораздо глубже. Фужины превратились в благополучный спальный район, дорогостоящий, как и вся Любляна, с домом для престарелых, с молодыми семьями и пенсионерами, где чефрурам, набравшим ипотечные кредиты, жить всё сложнее; а от той свободы, которой располагали они когда-то, будучи подростками, не осталось и следа:

Вот только чедурчиков ты больше нигде не увидишь. Ни во дворе, ни возле подъезда. Так как эти пара малявок, пялящихся в телефроны, в расчет не идут. У них ужасные треники и смешной причесон, да и скорее всего фрамилии на -ич, только это вовсе не чефуры. Чедруров на самом деле больше нет на Фужинах. Вымерли они. Вот вам еще один биологический вид, ставший жертвой климатических изменений, или как там это называется.

Но на самом деле всё логично. Чефруры переехали, так как квартиры на Фужинах слишком дорогие. У них роди- 
лись дети, и они стали старыми чефурами. Получили работу на складах, в пекарнях и на почте, и сами себе устроили подлянку, набрав ипотечные кредиты. Так-то оно. Долбаные кредиты уничтожили чефуров. Так как стоит чефуру взять кредит, его жизни конец. Чедрур в кредитах - мертвый чефрур. <..> Вот она, ассимиляция. Берет чефрур кредит и становится словенцем. Поэтому даже не нужно их вычеркивать ${ }^{2}$, достаточно кредитов, и разговор окончен. <...> Вместо того чтобы дебоширить, чефуры прилежно выплачивают кредиты. И все счастливы (Vojnović 2021: 26-27).

Во втором романе о Марко Джорджиче гораздо больше пространства приобретают Босния и куда более драматичная ситуация на Балканах. Герой отдалился от Фужин, стал частью жизни в Боснии и Герцеговине - мира беженцев, наполненного военными травмами и разрухой, - впитал в себя всё это болезненное боснийское прошлое, где разделение на своих и чужих по этническому и религиозному принципу лишь усугубляется. Процесс этнических чисток, начатый во время войны, по словам Войновича, не закончился, писатель сравнивает его с раком; Дейтоновские соглашения стали формой агрессивной химиотерапии, слегка замедлившей его дальнейшее распространение, но и только (Milek 2021). Это то лицо периферийной Боснии, на которое никто не желает смотреть, она исчезает, и уже совсем скоро ее невозможно будет увидеть, так же как и трансформирующееся пространство Словении; именно в этих тонких моментах в очередной раз, по словам писательницы Габриэлы Бабник, и демонстрирует свой уникальный талант Войнович-писатель (Babnik 2021). Его герой теперь отрезан от словенской действительности: во время его приезда в Любляну проходит чемпионат

2 «Вычеркнутые» (слов. izbrisani) - жители Словении, граждане Союзных Республик Югославии, которых Министерство внутренних дел Республики Словении 26 февраля 1992 г. незаконно вычеркнуло из регистра лиц, постоянно проживающих в Словении, лишив их связанных с этим экономических, медицинских и социальных прав. 
Европы по баскетболу 2017 г., где у словенской сборной есть все шансы на победу (в результате именно она и становится чемпионом, обыграв в финале в Стамбуле сборную Сербии); эта сборная могла бы быть его командой, так как это то же поколение игроков, однако Марко не верит в словенский потенциал и не в состоянии установить связь со здешней реальностью, вырвать себя из стигматизирующей чефурской среды, оторваться от нее эмоционально.

Таким образом, явление транскультурности в романе «Джорджич возвращается» приобретает еще большую комплексность: столкновение и наложение различных культурных пространств образует еще более многосоставную мозаику. Вопрос об идентичности встает тут гораздо радикальнее, пронзительнее, приобретая глубокие экзистенциальные ноты. Проблема «свой - чужой», с которой герой сталкивался в Словении, кажется смехотворной по сравнению с реалиями, которые возникают перед ним в Боснии:

Мне потребовалось сто лет, чтобы врубиться, что я серб и что серб в Високо - та же засада, что и чефур в Словении. Та же хрень, но в другой упаковке. Только вот в Боснии чефуры и словенцы стреляли один в другого, а не подкалывали друг друга неправильными формами родительных падежей и двойственного числа. Только я не мог быть еще раз чефуром. Без вариантов. Я мог бы быть кем угодно, трансвеститом, миротворцем UNPROFOR, монголоидом, цыганом Жарко, кем угодно, мать вашу, но только не чедуром опять. Так как я не мог снова иметь неподходящее имя. Я не мог смотреть, как люди сглатывают слюну, когда ты говоришь, что твоего старика зовут Радован. Этих заморочек мне хватило на Фужинах на три жизни вперед. <...> Мой план заключался в том, чтобы побыть какое-то время Янезом, а потом потихоньку затесаться среди местных и стать боснийцем, но только это был глупый план. Что там глупый, это был план, который отстал в развитии. Я был сперва обижен <..>, а потом понял, что везде один и тот же облом и что везде ты можешь выбирать лишь между тем, будешь ли меньшинством или же 
большинством. И я больше не хотел быть меньшинством. Мне хотелось немного побыть словенцем. <..> Я отправился в Биелину. К сербам. К тете Душанке и дяде Драгише. Свой среди своих, как сказал бы Радован (Vojnović 2021: 30).

Однако и попытка отнести себя к этнической группе на поверку оказывается обманом, герой везде чувствует свою непринадлежность окружающему пространству, где бы он ни был, несмотря на все усилия влиться в какую-либо среду, и ощущение чуждости не покидает его; называя себя «абсолютным отщепенцем» (Vojnović 2021: 32) на Фужинах, Марко невольно дает характеристику своему внутреннему состоянию. Он интуитивно понимает, что нет одной-единственной и стабильной идентичности и что вся его сила в этой способности перевоплощаться; через отрицание готовых решений, которые предлагает ему окружение, деструктивно подвергая себя неким губительным выборам, герой, возможно, открывает в себе новую личность, способность стать кем-то другим. В фринале романа мы видим Марко, который, взяв отцовский опель и отправившись в Високо к месту, откуда происходят его корни, к дому бабушки и деда, находящемуся в запустении и вовсе уже не принадлежащему семье Джорджич, пытается понять, кто же он. Это момент рождения некой новой идентичности, которая пока далека от каких-либо очертаемых фрорм:

Правда не знаю, что я тут делаю. Или всё же знаю. Я приехал посмотреть, всё ли я еще здесь. Всё ли я еще тут свой среди своих. Но только нет. Плевать я хотел на этот дом и на всё. Плевать мне на Фужины, плевать мне на Боснию, плевать мне на всё. Нигде меня нет. Я больше не чефур и не Янез. Я теперь лишь никто и ничто (Vojnović 2021: 319).

Язык романа в свою очередь является наиболее ярким отражением гибридной идентичности чефуров второго поколения, сложного наложения различных культурных пластов. Структура языковых регистров, выработанная в «Чедуры, 
вон!», получает здесь еще большую многогранность и представляет еще более богатый материал для лингвистического анализа. Мы всё так же имеем дело с родным языком чефруров - сербским или боснийским, межъязычием первого поколения иммигрантов, смешанным языком второго поколения, со свойственными ему двуязычием, гибридизацией двух языковых систем, свободным обращением с языковыми стереотипами, пародированием словенского литературного языка, обыгрыванием сербских народных присказок и пр. (об иммигрантских социолектах в романе «Чефруры, вон!» см.: [Красовец 2021]).

\section{Литература}

Красовец 2021 - Красовец А. Н. Иммигранты в Словении и их язык: роман Горана Войновича «Чедруры вон!» // На перекрестках Востока и Запада: проблемы пограничья в русской и центральноевропейских культурах $=$ At the crossroads of the East and the West: the problems of borderzone in Russian and Central European cultures / Ин-т славяноведения РАН; редкол.: Н. В. Злыднева (отв.ред.), Ж. Хетени (отв. ред.) [и др.]. М.: Ин-т славяноведения РАН, 2021. С. 127-156.

Babnik 2021 - Babnik G. Ker je to ipak moja zgodba. Zgodba Marka Đorđića // airBeletrina [сайт]. 23.04.2021. URL: http://www.airbeletrina. si/clanek/ker-je-to-ipak-moja-zgodba-zgodba-marka-dordica (дата обращения: 18.08.2021).

Milek 2021 - Milek $V$. Vsako pisanje izhaja iz bolečine. In bolečine so dedne // Delo. 13.03.2021. URL: https://www.delo.si/sobotna-priloga/ vsako-pisanje-izhaja-iz-bolecine-in-bolecine-so-dedne/ (дата обращения: 18.08.2021).

Vojnović 2021 - Vojnović G. Đorđić se vrača. Ljubljana: Beletrina, 2021.

\section{Issues of Transculturalism in Goran Voinović's Novel "Đorđić Returns" (2021)}

The novel by Slovenian writer Goran Voinović (1980) "Đorđić Returns" (2021) is a sequel to the author's debut novel "Southern Scum Go Home!" (2008), which turned to the life of first and second generation immigrants from the southern republics of the former 
Yugoslavia in Slovenia, and became a cult book. The author refers to the same characters and their evolution over the past ten years, a special place in the text is given to Bosnia and the life of the main protagonist there. The clash and overlap of different cultural spaces leads to complex forms of transculturalism, which are reflected in the work in the form of various forms of linguistic hybridity, bifurcated, nomadic identity of characters, actualization of the problem of migration as such.

М. М. Гролова (Москва, Россия)

\section{Словенские народные сказки и легенды в переводах на русский язык (с 1991 г. по настоящее время)}

Словенские народные сказки, активно собираемые и изучаемые на родине, русскоязычным читателям известны сравнительно мало. Их первые публикации на русском языке появляются во второй половине XIX в. в качестве иллюстративного материала в исследованиях видных ученыхславистов Ф.И. Буслаева и И.А. Бодуэна де Куртенэ, а затем и в популярных сборниках славянских сказок. После революции словенские сказки появляются в советских изданиях лишь по окончании советско-югославского конфликта 1948-1953 гг., причем дореволюционные переводы не перепечатываются.

В первые годы после распада СССР многочисленные новообразованные издательства охотно печатают сборники сказок - как правило, копии советских изданий или компиляции. Новые переводы сказок в это время редки: издательства в целях экономии обращаются к уже имеющимся. Переводы словенских сказок, выполненные в советский период, печатают до сих пор. Зачастую фрамилию переводчика 